\title{
KEMISKINAN DITINJAU DARI PERPEKSTIF AL-QURAN DAN HADIS
}

\author{
Bayu Tri Cahya \\ STAIN Kudus, Jawa Tengah, Indonesia \\ bayu_plur@yahoo.com
}

\begin{abstract}
PROV ERTY IN THE PERSPECTIVE OF QUR'AN AND $H A D I T H$. This paper aims to explain the poverty of view of alQuran and Hadith. This is because poverty is a global problem and a classic that is always there, and had a very large influence on individual and social life. Poverty is also a major enemy of the Muslims, they are obliged to fight against poverty he suffered. In Indonesia, poverty seems to be a necessity for the Indonesian people, especially Muslims. Irony indeed, poverty persists in the country that supposedly rich in natural resources. Most people understand the comparative poverty, while others look at it from the perspective of moral and evaluative, and others understand it from a scientific point of view that has been established. However, Islamic economics can be used as tools to save Muslims from poverty. Islam is not only limited economic alternatives, but the solution of the system of capitalism or any economic system which has been hailed by the West.
\end{abstract}

Keywords: Proverty, Economic System, Islamic Economy.

\begin{abstract}
Abstrak
Tulisan ini bertujuan untuk menjelaskan tentang kemiskinan dari pandangan al-Quran dan Hadis. Ini karena kemiskinan
\end{abstract}


adalah problema klasike dan global yang selalu ada, dan memiliki pengaruh sangat besar terhadap kehidupan individu maupun sosial. Kemisikinan juga merupakan musub besar umat Islam, mereka berkewajiban melawan kemiskinan yang menderanya. Di Indonesia, kemiskinan seolah menjadi suatu keniscayaan bagi masyarakat Indonesia, khususnya umat Islam. Ironi memang, kemiskinan tetap ada di negeri yang konon kaya akan berbagai sumber daya alam. Sebagian orang memahami kemiskinan secara komparatif, sementara yang lain melihatnya dari perspektif moral dan evaluatif, dan yang lain lagi memahaminya dari sudut ilmiah yang telab mapan. Namun, ekonomi Islam bisa dijadikan tools dalam menyelamatkean umat Islam dari kemiskinan. Ekonomi islam bukan hanya sebatas alternatif, melainkan solusi dari sistem kapitalisme atau sistem ekonomi manapun yang selama ini diagung-agungkean oleh Barat.

Kata Kunci: Kemiskinan, Sistem Ekonomi, Ekonomi Islam.

\section{A. Pendahuluan}

Masalah kemiskinan dianggap sebagai bagian dari masalah penting yang memiliki pengaruh besar terhadap kehidupan individu dan sosial. ${ }^{1}$ Kemiskinan menjadi problematika hidup yang sejak dahulu dihadapi manusia. Berbagai aturan dan sistem sosial, tidak mampu memberikan jalan keluar dari permasalahan tersebut dan inilah penyebab maraknya berbagai kejahatan dan pertikaian antara sesama manusia di tengah tengah kehidupan kita.

Dahulu ada ungkapan yang mengakar kuat dalam masyarakat, bahwa orang-orang miskin adalah kelompok masyarakat yang berada pada tingkat yang paling rendah, keberadaan mereka merupakan penyakit masyarakat yang paling buruk. Maka dari itu, faktor kemiskinan dapat mendorong orang-orang yang mengalaminya untuk melakukan berbagai macam tindak kejahatan, demi mendapatkan kebutuhan hidup yang paling pokok yaitu, makanan. Bukankah perut bila terasa lapar mendorong pemiliknya melakukan berbagai kejahatan, dan

${ }^{1}$ Mahmud Ahmad Sa'id al-Athrasy, Hikmah di Balik Kemiskinan, Jakarta: Qisthi Press, 2013), hlm.1. 
Kemiskinan Ditinjau Dari Perpekstif Al-Quran dan Hadis

bahkan perkara itu sudah (dianggap) sebagai perbuatan yang dibenarkan.

Pada lingkungan masyarakat miskin, semua ideologi yang ekstrim banyak diminati dan semua perbuatan keji pun dihalalkan untuk memenuhi keinginan-keinginan. ${ }^{2}$ Perkara ini pernah terjadi pada masa Jahiliyah. Saat itu, orang orang tega membunuh anakanak mereka (darah daging mereka) karena perasaan takut terhina oleh kemiskinan sebagaimana mereka melihat sebagian pengaruh kemiskinan yang membahayakan kehidupan seseorang. Orang miskin menjalani hidup penuh rasa cemas, gelisah, dan duka. Dia menghabiskan waktu dan hidupnya untuk mendapatkan harta. Dalam kitab Ibjā Ulum ad-Din, al-Ghazali ${ }^{3}$ berkata;

"Orang miskin tidak memiliki kecukupan dalam menuntut ilmu dan kesempurnaan, usabanya sama seperti orang pergi ke "baija" tanpa membawa senjata. Bagaimana tidak demikian, sedangkan orang yang tiada berbarta akan menjadi orang menggunakan selurub waktu bidupnya sekedar untuk mencari makan, mendapatkan pakaian, tempat tinggal dan kebutuban kebutuban bidup lainnya. Kemudian, ia akan menghadapi berbagai macam rintangan yang dapat melalaikan dirinya dari berdzikir dan berfikir. Semua itu tidak bisa dicegah kecuali bersenjatakan harta. Sebagian orang bijak (saat ditanyakan kepadanya), Apa itu kenikmatan? Ia menjawab; "Kenikmatan itu adalah kenyataan. Karena sesungguhnya aku melihat orang miskin tiada memiliki kehidupan."

Beberapa agama, aliran, dan kelompok filsafat telah berusaha memecahkan masalah kemiskinan ini. Berbagai teori dan falsafah pun bermunculan untuk mengentaskannya. Namun sungguh, masalah ini belum juga teratasi secara logis atau diterima akal sehat, sampai Islam datang dan memberikan solusi yang detail dalam mengenai masalah tersebut. Sampai pada

${ }^{2}$ Alif Thabarah, Ruh ad-Din as-Islami, Cet. Ke-27 (Beirut: Dar al- Ilmi li al-Malayin, 1988), hlm. 343.

${ }^{3}$ Umar Ridho Kahalah, Mu'jam al-Mu'allifin, Juz 3, cet. Ke-1 (Beirut: Muassasah ar-Risalah, t.t) hlm, 671.

${ }^{4}$ Al-Haija berarti peperangan. Lihat: Muhammad ibn Abu Bakar ar Razi, Mubktar ash-Shahah, (Damaskus: Mu'assasah Ilmu al-Quraan dan Dar al-Qiblah al-Islamiyah, $1405 \mathrm{H} / 1985 \mathrm{M})$ hlm. 703.

${ }^{5}$ Al-Gazali, Ihya' Ulum ad-Din, Juz 4, Cet. Ke-1 (Kairo: Dar asy-Sya'b), hlm. 134. 
akhirnya, masyarakat islam melewati masa di mana orang-orang yang masyarakat Islam melewati masa di mana orang-orang yang berhak menerima zakat diseru untuk diberikan bagian zakatnya, namun tidak satu pun dari mereka, orang orang yang berhak menerima zakat ditemukan. Kebanyakkan gerakan dan ideologi yang menyerukan pemecahan masalah demi kemiskinan sangat ekstrim. Gerakan tersebut mengajak orang kaya untuk melakukan kebajikan secara individual, maupun kepada orang miskin yang beban hidupnya wajib menjadi tanggungan orang kaya.

Sejak dahulu, beberapa agama dan kelompok aliran falsafah telah berupaya memecahkan problematika kemiskinan dan meringankan beban hidup yang ditanggung orang-orang miskin. Caranya beragam, terkadang melalui penyampaian wasiat, nasihat, anjuran-anjuran, dan peringatan-peringatan. Terdapat perbedaan cara mengupas materi secara teoritis tentang wujud kehidupan yang ideal di atas bumi, yang tidak ada perbedaan derajat ataupun pembagian kasta-kasta manusia dan tidak ada kefakiran ataupun kemiskinan. Problem ini masih menjadi problem terpenting yang tengah dihadapi oleh masyarakat-masyarakat modern saat ini dan mereka berupaya menemukan jalan keluarnya. Barangkali, segala perselisihan yang terjadi pada dunia saat ini kembali kepada masalah kemiskinan yang ada dan kepada upaya menemukan cara yang mungkin dapat mengatasinya. Pada satu sisi, sistem kapitalisme berpendirian dengan ide kabajikan individu, yang mendatangkan pertolongan bagi orang-orang miskin dan orang kaya akan membelanya berdasarkan kesukaan dan pilihannya. Namun disisi lain sosialisme menerapkan sistem menyita orangorang kaya sebagai pemilik negara setelah itu negara melakukan tindakan-tindakan dalam mengatasi kemiskinan. ${ }^{6}$ Oleh karena itu, artikel ini bertujuan untuk memaparkan kajian secara empiris tentang kemiskinan ditinjau dari perspektid al-Quran dan Hadis.

${ }^{6}$ Abdul Haq asy-Syakiri, at-Tanmiyyah al Iqtishadiyyah fi al-Islam, (Qatar: Kitab al-Ummah, no 17, 1408 H), hlm. 109. 


\section{B. Pembahasan}

\section{Fakir dan Miskin dalam al-Quran dan Hadis}

\section{a. Makna fakir menurut bahasa}

Kata fakir menunjukkan kepada seseorang yang memiliki sedikit atau tidak memiliki harta sama sekali. Menurut bahasa, kata faqrun, maknanya adalah hal yang lepas dari segala sesuatu, baik bagian dari anggota tubuhnya ataupun yang lainnya. ${ }^{7}$

Ibnu Faris berkata; " $f a$, qaf dan ra merupakan huruf asli dan sahih yang menandakan pada hal yang lepas dari sesuatu, baik itu dari bagian anggota tubuh ataupun yang lainnya. Jadi, faqir adalah patah tulang-tulang punggungnya. Para ahli bahasa berkata; kata faqir diambil dari faqrun, seakan-akan orang fakir adalah orang yang patah tulang punggunya karena tergelincir dari kehinaan dan kemiskinannya. ${ }^{8}$

Dalam al-Quran sendiri terdapat 8 ayat yang mengandung kata fakir (baik dalam bentuk tunggal maupun jamak), yaitu sebagai berikut;

\begin{tabular}{|c|c|c|c|c|}
\hline No & Surat & Ayat ke & Kata & Terjemah \\
\hline 1 & Al-Baqarah & 271 & الفقراء & Orang-orang fakir \\
\hline 2 & Al-Baqarah & 273 & للفقراء & Bagi orang-orang fakir \\
\hline 3 & AN-Nisa & 6 & فقيرا & Fakir/miskin \\
\hline 4 & At-Taubah & 60 & للفقراء & Untuk orang-orang fakir \\
\hline 5 & Al-Hajj & 28 & الفقير & Orang-orang yang fakir \\
\hline 6 & An-Nūr & 32 & فقراء & Fakir \\
\hline 7 & Muhammad & 38 & لـفراء & Fakir/berkeperluan \\
\hline 8 & Al-Hasr & 8 & للفقراء & Bagi orang-orang fakir \\
\hline
\end{tabular}

${ }^{7}$ Mahmud Ahmad Sa'id, Hikmah di Balike, hlm. 9.

${ }^{8}$ Ibnu Faris, Mu'jam Maqayis al- Lughah, Juz 4, Cet. Ke-1 (Beirut, Dar alJail, 1420 H/1999 M), hlm. 444. 
Dari tabel di atas dapat diketahui bahwa kata faqir maupun fuqara relatif memiliki makna yang sama, yaitu orang-orang fakir. Terkait dengan definisi fakir, dalam riwayat Abu Hurairah r.a., Nabi saw. bersabda yang artinya; "Telab menceritakan kepada kami Abdullah bin Maslamah, telah menceritakan kepada kami Sufyan dari Az-Zubri dari Humaid dari Abu Hurairah, ia berkata; Seorang lelaki menemui Nabi saw. dan berujar; Celaka aku! Nabi bertanya: "Ada apa dengan kamu?" jawabnya; Aku menggauli isteriku di bulan Ramadhan.' Nabi saw. bertanya: "Apakah engkau mempunyai seorang budak yang bisa kamu bebaskan?" 'tidak' jawabnya. Nabi bertanya lagi: "Apakah kamu bisa berpuasa selama dua bulan berturut-turut?” Tidak, jawabnya. Nabi bertanya lagi: "mampukah kamu memberi makan enam pulub orang miskin?" Tidak, jawabnya. Kemudian Nabi saw. memberi segantang kurma dan berujar: "Ambilah kurma ini dan bersedekah dengannya!" ia menjawab; Apakah kepada orang yang lebih fakir daripada saya? Sungguh diantara dua gunung ini tidak ada orang yang lebih fakir daripada aku!" maka Nabi berujar: "Ambillah dan berilah makan keluargamu denganya."

Sedangkan menurut Kamus Besar Bahasa Indonesia, fakir diartikan sebagai orang yang dengan sengaja membuat dirinya menderita kekurangan (untuk mencapai kesempurnaan batin. ${ }^{10}$

\section{b. Makna Miskin Menurut Bahasa}

Kata Miskin asal katanya adalah as-sakan, artinya yaitu lawan kata dari hal yang selalu bergolak dan bergerak. Ibnu Faris berkata; "Huruf sin, kaf dan nun adalah huruf asli dan umum menandakan pada suatu makna kebalikan dari hal yang bergerak dan bergejolak, seperti dikatakan, 'Sakana asy-syai'u yaskunu sukunan sakinan. ${ }^{11}$

9 Abu Abdullah Muhammad ibn Ismail Al-Bukhari, Al-Jami' Ash-Shabih, juz 4, (Kairo: Maktabah Salafiyah, 1400 H), hlm. 231-232.

${ }^{10}$ Tim Penyusun, Kamus Besar Bahasa Indonesia, (Jakarta: Pusat Bahasa D partemen Pendidikan Nasional, 2008), hlm. 97.

${ }^{11}$ Ibnu Faris, Mu'jam Maqayis, Juz 3, hlm. 88. 
Kemiskinan Ditinjau Dari Perpekstif Al-Quran dan Hadis

Sehingga bisa diartikan orang miskin adalah orang yang ditenangkan oleh kefakiran dan ia adalah orang yang sama sekali tidak memiliki apa-apa, atau orang yang memiliki sesuatu yang tidak mencukupi kebutuhannya. Seorang dikatakan miskin, dikarenakan kondisi dan situasinya benar-benar telah membuat geraknya menjadi sedikit lalu mencegahnya untuk bergerak, atau bisa juga berarti orang yang berdiam diri di rumah saja dan enggan pergi meminta-minta kepada manusia.

Dalam al-Quran sendiri terdapat 33 ayat yang mengandung kata miskin (baik dalam bentuk tunggal maupun jamak), dimana sebagian besar berasal dari kata dasar as-sakan (sebanyak 27 ayat), yaitu sebagai berikut;

\begin{tabular}{|c|c|c|c|c|}
\hline No. & Surat & Ayat ke & Kata & Terjemah \\
\hline 1 & Al-Baqarah & 83 & و المسكين & $\begin{array}{l}\text { Dan orang-orang } \\
\text { miskin }\end{array}$ \\
\hline 2 & Al-Baqarah & 177 & و المسكين & $\begin{array}{l}\text { Dan orang-orang } \\
\text { miskin }\end{array}$ \\
\hline 3 & Al-Baqarah & 184 & مسكين & Seorang miskin \\
\hline 4 & Al-Baqarah & 215 & و المسكين & $\begin{array}{l}\text { Dan orang-orang } \\
\text { miskin }\end{array}$ \\
\hline 5 & Al-Baqarah & 268 & الفقر & Kemiskinan \\
\hline 6 & Al-Imran & 181 & فقير & Miskin \\
\hline 7 & AN-Nisa & 6 & فقيرا & Fakir/miskin \\
\hline 8 & AN-Nisa & 8 & و المسكين & $\begin{array}{l}\text { Dan orang-orang } \\
\text { miskin }\end{array}$ \\
\hline 9 & AN-Nisa & 36 & و المسكين & $\begin{array}{l}\text { Dan orang-orang } \\
\text { miskin }\end{array}$ \\
\hline 10 & AN-Nisa & 135 & فقيرا & Miskin \\
\hline 11 & Al-Maidah & 89 & مسكين & Orang-orang miskin \\
\hline
\end{tabular}


Bayu Tri Cahya

\begin{tabular}{lllll}
\hline 12 & Al-Maidah & 95 & مسكين & Orang-orang miskin \\
\hline 13 & Al-Anfal & 41 & Dan orang-orang \\
miskin
\end{tabular}

Sedangkan sisanya, kata yang berarti miskin yang tidak berasal dari as-sakan terdapat dalam 5 ayat, yaitu sebagai berikut:

\begin{tabular}{lllll}
\hline No. & Surat & Ayat ke & Kata & Terjemah \\
\hline 28 & Al-Baqarah & 236 & المقتر & orang yang miskin \\
\hline
\end{tabular}


Kemiskinan Ditinjau Dari Perpekstif Al-Quran dan Hadis

\begin{tabular}{lllll}
\hline 29 & Al-An'am & 151 & إملق & Kemiskinan \\
\hline 30 & At-Taubah & 28 & عenjadi miskin \\
\hline 31 & Al-Isra & 31 & عائل & keapaan/kemiskinan \\
\hline 32 & Ad-Duha & 8 & miskin/kekurangan \\
\hline
\end{tabular}

Dari tabel di atas dapat diketahui bahwa kata miskin relatif memiliki makna yang sama, yaitu orang-orang miskin. Terkait dengan definisi miskin, dalam riwayat Abu Hurairah ra., Nabi saw, bersabda yang artinya; "Telah menceritakan kepada kami Ibnu Abu Maryam, telah menceritakan kepada kami Mubammad bin Ja'far, ia berkata; Telah menceritakan kepadaku Syarik bin Abu Namir bahwa Atha bin Yasar dan Abdurrahman bin Abu 'Amrah Al-Anshari keduanya berkata; Kami mendengar Abu Hurairah r. a berkata; Nabi saw. bersabda: "Orang yang miskin bukanlah orang yang merasa telah cukup dengan satu atau dua buah kurma, atau sesuap atau dua suap makanan. Tetapi orang miskin adalah orang yang tidak meminta-minta dan menunjukan kemiskinannya kepada orang lain. Jika kalian mau, bacalah firman Allab: "Mereka tidak meminta-minta kepada orang lain." (H. R. Al-Bukhari). ${ }^{12}$

Masih melalui jalur riwayat yang sama seperti hadis sebelumnya; dari Abu Hurairah; Dan Rasulullah saw. bersabda: "Bukanlah orang yang miskin itu orang yang selalu keliling kepada manusia, ia tertolak untuk mendapat satu atau dua suap, satu kurma atau dua kurma, tetapi yang disebut orang miskin adalah orang yang tidak mendapat sesuatu yang mencukupinya, ia malu untuk meminta-minta kepada manusia, dan tidak ada orang yang tahu sehingga bisa bersedekah kepadanya."13

${ }^{12}$ Abu Abdullah Muhammad ibn Ismail Al-Bukhari, Al-Jami', hlm. 205.

${ }^{13}$ Imam Ahmad ibn Muhammad ibn Hanbal, Al-Musnad, Juz 8, (Kairo: Dar al-Hadits), hlm. 227. 
Sedangkan menurut Kamus Besar Bahasa Indonesia, miskin diartikan sebagai tidak berharta benda; serba kekurangan (berpenghasilan sangat rendah). ${ }^{14}$

\section{c. Antara fakir dan miskin}

Adanya perbedaan pendapat seputar sebutan orang yang tidak memiliki apa-apa dengan kata al-Miskin telah menyebabkan munculnya silang pendapat tentang perbedaan fakir dan miskin. Ada pun beberapa ayat-ayat al-Quran menegaskan tentang kata fakir dan miskin, diantaranya adalah ayat 79 surat al-Kahfi yang artinya; "Adapun babtera itu adalah kepunyaan orang-orang miskin yang bekerja di laut, dan aku bertujuan merusakkan babtera itu, karena di hadapan mereka ada seorang raja yang merampas tiap-tiap babtera." (Q. S. Al-Kahfi (18): 79).

Ayat ini menegaskan bahwa orang miskin itu lebih baik keadaannya daripada orang fakir dikarenakan mereka memiliki perahu atau bahtera yang dapat dijadikan alat untuk mencari nafkah. Di samping itu, dari asal kata, kata faqir adalah isim fa'ïl yang bermakna maful, yaitu orang yang dipatahkan tulang rusuknya. Sedangkan kata miskin terambil dari kata as-sukun (diam atau tenang) sehingga dapat diambil kesimpulan bahwa orang yang patah tulang rusuknya lebih parah kedaannya daripada orang yang diam (tidak bekerja). Orang-orang tersebut yang tidak memiliki kemampuan untuk membela diri mereka dari kejahatan raja lalim, yang telah merampas setiap bahtera yang tampak. Jadi, tentu saja bahtera itu bukanlah milik orang miskin yang tidak memiliki harta.

Allah swt. juga menegaskan di ayat yang lain yang artinya; "Atau kepada orang miskin yang sangat fakir." (Q. S. Al-Balad (18): 16).

Ayat ini menjelaskan bahwa yang bernama miskin itu adalah orang yang tidak memiliki apa-apa, atau yang menurut

${ }^{14}$ Ibnu Faris, Mu'jam Maqayis, hlm. 961. 
bahasa seperti ucapan Ibnu Katsir, "Orang miskin itu adalah orang yang terlantar dan terbuang di jalan."

Silang pendapat justru terlihat dari beberapa kalangan ulama terkait makna fakir dan miskin, diantaranya pendapat Ibnu Sikt, orang miskin adalah orang yang tidak memiliki apa-apa, adapun orang fakir adalah orang yang memiliki kehidupan paspasan. Yunus juga mengatakan; "Orang fakir dijadikan keadaanya lebih baik daripada miskin. Dia berkata; "Aku pernah bertanya pada seorang baduwi; "Apakah kamu orang fakir?' Si baduwi menjawab; Tidak, tetapi demi Allah aku ini adalah orang miskin." Al-Ashmui berkata; "Orang miskin itu lebih baik keadaanya daripada orang fakir." 15

Ulama Hanafiyah dan Malikiyah berpendapat bahwa orang miskin lebih parah kondisinya daripada orang fakir. Abu Hainifah berpendapat, miskin lebih buruk kondisinya dibanding fakir. Pendapatnya didasarkan pada riwayat yang diterima dari Ibnu Jarir bahwa Umar ra. berkata: fakir bukan yang tidak punya harta, tetapi orang yang tidak punya usaba. Sementara menurut mayoritas ulama adalah sebaliknya, bahwa fakir lebih buruk keadaannya dibanding miskin. Pendapat Jumhur didukung oleh pendapat Ibnu Abbas yang membedakan bahwa fakir adalah orang yang menahan diri dari meminta-minta sesuatu kepada manusia, sementara miskin adalah orang yang berkeliaran meminta-minta di tengah manusia (masyarakat). Sementara Qatadah berpendapat bahwa fakir adalah orang yang menderita karena penyakit, sementara miskin sehat secara fisik. ${ }^{16}$

\section{d. Standar Miskin Dalam al-Quran dan Hadis}

Fakir dan miskin adalah golongan orang-orang yang tidak mampu untuk memenuhi kebutuhan mereka sendiri. Dan apabila kata miskin disebutkan secara sendiri maka kata tersebut mencakup juga golongan fakir demikian juga sebaliknya.Tetapi

${ }^{15}$ Mahmud Ahmad Sa'id, Hikmah di Balik, hlm. 9.

${ }^{16}$ Ibn Katsir, Tafsir Al-Quran al-Karim, (Libanon: Maktabah Aulad li asSyaikh li at-Turats, t.t.), hlm. 219-220. 
jika keduanya disebutkan secara berbarengan, para ulama berbeda pendapat tentang mana diantara mereka yang paling memerlukan bantuan.

Kriteria fakir dan miskin sebagaimana telah dipaparkan dalam surat At-Taubah ayat 60, mereka adalah pihak-pihak yang berhak menerima zakat. Pada firman Allah swt. yang lain pada surat al-Kahfi ayat 79, menegaskan bahwa orang miskin itu lebih baik keadaannya daripada orang fakir dikarenakan mereka memiliki perahu atau bahtera yang dapat dijadikan alat untuk mencari nafkah. Begitu pula yang terdapat dalam surat al-Balad ayat 16 yang menerangkan keadaan miskin yang sangat. Dari penjelasan para ulama di atas dapat kita pahami bahwa kriteria seseorang dikatakan miskin atau fakir adalah jika orang tersebut tidak mampu untuk memenuhi kebutuhan hidupnya.

\section{Perintah al-Quran dan Hadis untuk Membantu Orang- orang Miskin}

Pada dasarnya Islam tidak mentolerir segala bentuk kemiskinan bagi para pemeluknya. Islam memerintahkan dengan tegas supaya umatnya berzakat, berinfak, membiayai peperangan itu sendiri, diperintahkan untuk menjalankan haji dan sebagainya. Bagaimana mungkin, orang orang miskin bisa melakukan semua perintah tersebut. Secara tersurat perintah ini hanya dapat dilakukan oleh orang orang yang berilmu pengetahuan dan memiliki harta. Hal ini seperti yang tertuang dalam ayat 60 surat al-Anfal yang artinya; "Dan siapkanlah untuk menghadapi mereka kekuatan apa saja yang kamu sanggupi dan dari kuda-kuda yang ditambat untuk berperang (yang dengan persiapan itu) kamu menggentarkan musuh Allah dan musubmu dan orang orang selain mereka yang kamu tidak mengetahuinya; sedang Allab mengetabuinya. Apa saja yang kamu nafkabkan pada jalan Allah niscaya akan dibalasi 
Kemiskinan Ditinjau Dari Perpekstif Al-Quran dan Hadis

dengan cukup kepadamu dan kamu tidak akan dianiaya (dirugikan)." (Q. S. Al-Anfal (08): 60)

Dapat ditarik benang merahnya dari ayat di atas bahwa ajaran Islam itu mendorong masyarakatnya untuk memiliki harta kekayaaan dalam menghadapi musuh Islam. Kemisikinan adalah musuh besar umat Islam, mereka berkewajiban melawan kemiskinan yang menderanya. Allah swt., tidak pernah memerintahkan penganutnya menjadi orang miskin, kalau kita baca seluruh ayat dalam al-Quran, maka tidak akan pernah menjumpai ayat yang memerintahkan umat Islam menjadi miskin. Allah itu Maha Penyayang, Dia akan membantu umatnya keluar dari segala kesulitan. ${ }^{17}$

Mungkin pernah terlintas di benak umat Islam bahwa kemiskinan yang dialami seseorang yang disebabkan karena keturunan dan tidak mungkin bisa berubah. Pikiran tersebut adalah pikiran yang salah. Pikiran tersebut adalah pikiran yang salah. Manusia bisa saja merubah nasibnya kalau dia mempunyai keinginan untuk merubah. Pada dasarnya Allah akan memberi rezeki pada setiap orang yang berusaha untuk mendapatkan rezeki-Nya. Allah akan memberi jalan keluar dari setiap masalah yang dihadapinya, mereka tidak boleh berputus asa dalam menghadapi berbagai kesulitan. Kesulitan adalah seni untuk mencapai sesuatu yang ideal. Orang tidak akan merasakan suatu keindahan kalau mereka tidak pernah merasakan sesuatu yang buruk. Orang tidak akan merasakan betapa nikmatnya kekayaan memiliki kalau mereka tidak pernah merasakan betapa susahnya menjalani kehidupan yang serba kekurangan.

Islam dengan ajarannya yang suci selalu memberikan jalan keluar bagaimana seharusnya menghadapi kemiskinan. Umat Islam yang kaya diperintahkan untuk menyantuni mereka yang hidupnya serba kekurangan (miskin). Dengan tegas, Allah swt dalam firman-Nya menganpologikan bahwa orang yang

\section{hlm. 5 .}

${ }^{17}$ Jafril Khalil, Jihad Ekonomi Islam, (Jakarta, Gramata Publishing, 2010), 
membiarkan sesamanya kelaparan sama saja dengan mendustkan agama yang agung. Al-Quran mewajibkan kepada setiap Muslim untuk berpartisipasi menanggulangi kemiskinan sesuai dengan kemampuannya. Bagi yang tidak memiliki kemampuan material, maka paling sedikit partisipasinya diharapkan dalam bentuk merasakan, memikirkan, dan mendorong pihak lain untuk berpartisipasi aktif.

Secara tegas Al-Quran mencap mereka yang enggan berpartisipasi (walau dalam bentuk minimal) sebagai orang yang telah mendustakan agama dan hari kemudian, seperti yang tertuang dalam surat al-Ma'un ayat 1-3 yang artinya; 'Tahukah kamu (orang) yang mendustakan agama? Itulah orang yang menghardik. anak yatim, dan tidak menganjurkan memberi Makan orang miskin." (Q. S. Al-Ma'un (107): 1-3)

Di dalam ayat tersebut secara tegas Islam menyatakan bahwa orang-orang miskin dan anak yatim mesti diberikan santunan. Namun arti sesungguhnya dari ayat tersebut adalah bahwa umat islam yang hidupnya berkecukupan secara materi dan akhirnya mampu menjalankan perintah agama secara tenang.

Apakah umat Islam yang hidupnya berkecukupan tega melihat saudara nya tersebut dalam penderitaan, sedangkan Rasulullah mengajarkan bahwa "tidak sempurna iman seseorang kalau ia tidak mencintai saudaranya sebagaiman ia mencintai dirinya sendiri". Disamping itu perintah memudahkan kesulitan suatu mukmin juga tertuang dalam sebuah hadis yang artinya: "Barangsiapa menghilangkan satu kesusaban dunia dari seorang mukmin, Allab akan menghilangkan darinya satu kesusahan di hari Kiamat. Dan barangsiapa yang memudabkan kesulitan orang yang dililit butang, Allah akan memudabkan atasnya di dunia dan akbirat." (HR. Abu Dawud) ${ }^{18}$

Dalam hal ini mungkin ada yang mempertanyakan, apakah Rasulullah memperjuangkan Islam dengan harta kekayaan?

${ }^{18}$ Abu Daud Sulaiman ibn Asy'ats As-Sijistani, Sunan Abi Daud, (Riyadh: Maktabah Ma'arif, t.t,), hlm. 894. 
Jawabannya adalah Ya. Tanpa bantuan dari para sahabat dan isterinya, Khadijah yang memiliki harta, tentu sangat sulit bagi umat islam di bawah kepemimpinan Rasulullah saw. untuk melawan suku Quraisy. Rasulullah saw. adalah orang kaya karena didukung perjuangannya oleh Khadijah, dan dengan kekayaannya itulah beliau dan para sahabat menegakkan agama Islam. Sebelum diangkat menjadi Rasul, beliau telah mengumpulkan banyak harta, dimana harta itu digunakan untuk menegakkan agama Allah. Makanya, kita sebagai orang muslim harus mampu berjuang dan mendapatkan harta dan menggunakan untuk kepentingan Allah.

\section{Cara Penanggulangan Kemiskinan dalam Al-Quran dan}

\section{Hadis}

Dalam rangka mengentaskan kemiskinan, Al-Quran menganjurkan banyak cara yang harus ditempuh, yang secara garis besar dapat dibagi pada tiga hal pokok;

\section{a. Kewajiban setiap individu}

Kerja dan usaha merupakan cara pertama dan utama yang ditekankan oleh kitab suci al-Quran, karena hal inilah yang sejalan dengan naluri manusia, sekaligus juga merupakan kehormatan dan harga dirinya. ${ }^{19}$ Dijadikan indah dalam (pandangan) manusia kesenangan kepada syahwat, berupa wanita (lawan seks), harta yang banyak dari jenis emas dan perak, kuda pilihan, binatang ternak, dan sawah ladang. Itulah kesenangan hidup duniawi seperti yang dijelaskan dalam surat Ali 'Imran ayat 14 yang artinya;

"Dijadikan indah pada (pandangan) manusia kecintaan kepada apa-apa yang diingini, yaitu: wanita-wanita, anak-anak, barta yang banyak dari jenis emas, perak, kuda piliban, binatang-binatang ternak dan sawab ladang. Itulab kesenangan bidup di dunia, dan di sisi Allah-lah tempat kembali yang baik. (surga).”(Q. S. Ali Imran [3]: 14)

Ayat ini secara tegas menggarisbawahi dua naluri manusia, yaitu naluri seksual yang dilukiskan sebagai "kesenangan kepada syahwat wanita" (lawan jenis), dan naluri kepemilikan

${ }^{19}$ M. Quraish Shihab, Wawasan al-Quran, Cet. Ke-13. (Bandung: Mizan, 2009), hlm. 393. 
yang dipahami dari ungkapan (kesenangan kepada) "harta yang banyak".

Sementara pakar menyatakan bahwa seakan-akan alQuran menjadikan kedua naluri itu sebagai naluri pokok manusia. Bukankah teks ayat tersebut membatasi (hashr) kesenangan hidup duniawi pada hasil penggunaan kedua naluri itu?

Kalau demikian kerja dan usaha merupakan dasar utama dalam memperoleh kecukupan dan kelebihan. Sedang mengharapkan usaha orang lain untuk keperluan itu, lahir dari adat kebiasaan dan di luar naluri manusia. Memang, lanjut Ibnu Khaldun, kebiasaan dapat membawa manusia jauh dari hakikat kemanusiaannya.

Dari sini dapat disimpulkan bahwa jalan pertama dan utama yang diajarkan al-Quran untuk pengentasan kemiskinan adalah kerja dan usaha yang diwajibkan atas setiap individu yang mampu. Puluhan ayat telah memerintahkan dan mengisyaratkan kemuliaan bekerja. Segala pekerjaan dan usaha halal dipujinya, sedangkan segala bentuk pengangguran dikecam dan dicelanya seperti yang terdapat di dalam surat Alam Nasyrah ayat 7-8 yang artinya;

"Maka apabila kamu telab selesai (dari sesuatu urusan), kerjakanlah dengan sunggub-sunggub (urusan) yang lain, dan hanya kepada Tubanmulah bendaknya kamu berbarap.” (Q. S. Alam Nasyrah [94]: 7-8)

Kalau di tempat seseorang berdomisili tidak ditemukan lapangan pekerjaan, al-Quran menganjurkan kepada orang tersebut untuk berhijrah mencari di tempat lain, dan ketika itu pasti dia bertemu di bumi ini, tempat perlindungan yang banyak dan keluasan, seperti yang dinyatakan di dalam surat an-Nisa' ayat 100 yang artinya;.

"Barangsiapa berbijrah di jalan Allah, niscaya mereka mendapati di muka bumi ini tempat hijrah yang luas dan rezeki yang banyak. Barangsiapa keluar dari rumabnya dengan maksud berbijrah kepada Allah dan Rasul-Nya, kemudian kematian menimpanya (sebelum sampai ke tempat yang dituju), Maka sunggub telah tetap pahalanya di sisi Allah. Dan adalah Allah Maha Pengampun lagi Maha Penyayang.” (Q. S. an-Nisa' [4]: 100). 


\section{b. Kewajiban masyarakat}

Sebelum menguraikan cara kedua ini, perlu terlebih dahulu digarisbawahi bahwa menggantungkan penanggulangan problem kemiskinan semata-mata kepada sumbangan sukarela dan keinsafan pribadi, tidak dapat diandalkan. Teori ini telah dipraktekkan berabad-abad lamanya, namun hasilnya tidak pernah memuaskan. Sementara orang sering kali tidak merasa bahwa mereka mempunyai tanggung jawab sosial, walaupun ia telah memiliki kelebihan harta kekayaan. Karena itu diperlukan adanya penetapan hak dan kewajiban agar tanggung jawab keadilan sosial dapat terlaksana dengan baik.

Dalam hal ini, al-Quran walaupun menganjurkan sumbangan sukarela dan menekankan keinsafan pribadi, namun dalam beberapa hal Kitab Suci ini menekankan hak dan kewajiban, baik melalui kewajiban zakat, yang merupakan hak delapan kelompok yang ditetapkan dalam surat at-Taubah ayat 60, maupun melalui sedekah wajib yang merupakan hak bagi yang meminta atau yang tidak, namun membutuhkan bantuan. "Dalam harta mereka ada hak untuk (orang miskin yang meminta) dan yang tidak berkecukupan (walaupun tidak meminta)." (Q. S. Al-Dzariyat (51): 19). Hak dan kewajiban tersebut mempunyai kekuatan tersendiri, karena keduanya dapat melahirkan "paksaan" kepada yang berkewajiban untuk melaksanakannya. Bukan hanya paksaan dan lubuk hatinya, tetapi juga atas dasar bahwa pemerintah dapat tampil memaksakan pelaksanaan kewajiban tersebut untuk diserahkan kepada pemilik haknya.

Dalam konteks inilah al-Quran menetapkan kewajiban membantu keluarga oleh rumpun keluarganya, dan kewajiban setiap individu untuk membantu anggota masyarakatnya, melalui cara sebagai berikut; ${ }^{20}$

${ }^{20}$ Ibid., h. 342. 
1) Jaminan satu rumpun keluarga

Boleh jadi karena satu dan lain hal seseorang tidak mampu memperoleh kecukupan untuk kebutuhan pokoknya, maka dalam hal ini al-Quran datang dengan konsep kewajiban memberi nafkah kepada keluarga, atau dengan istilah lain jaminan antar satu rumpun keluarga sehingga setiap keluarga harus saling menjamin dan mencukupi. Orang-orang yang berhubungan kerabat itu sebagian lebih berhak terhadap sesamanya (daripada yang bukan kerabat) (Q. S. Al-Anfal (8): 75). Dan berikanlah kepada keluarga dekat haknya, juga kepada orang miskin, dan orang yang berada dalam perjalanan (Q. S. al-Isra' (17): 26).

Ayat di atas menggarisbawahi adanya hak bagi keluarga yang tidak mampu terhadap yang mampu. Dalam mazhab Abu Hanifah memberi nafkah kepada anak dan cucu, atau ayah dan kakek merupakan kewajiban walaupun mereka bukan muslim. Para ahli hukum menetapkan bahwa yang dimaksud dengan nafkah mencakup sandang, pangan, papan dan perabotnya, pelayan (bagi yang memerlukan), mengawinkan anak bila tiba saatnya, serta belanja untuk istri dan siapa saja yang menjadi tanggungan. Begitu juga yang tertuang dalam firman Allah swt. dibawah ini yang artinya;

"Hendaklah orang yang mampu memberi nafkah menurut kemampuannya. Dan orang yang disempitkan rezekinya hendaklah memberi nafkah dari harta yang diberikan Allah kepadanya. Allah tidak memikulkan beban kepada seseorang melainkan sekedar apa yang Allah berikan kepadanya. Allab kelak akan memberikan kelapangan sesudah kesempitan”. (Q. S. At-Thalaq (65): 7)

2) Zakat

Dari sekumpulan ayat-ayat al-Quran dapat disimpulkan bahwa kewajiban zakat dan kewajiban-kewajiban keuangan lainnya, ditetapkan Allah berdasarkan pemilikan-Nya yang mutlak atas segala sesuatu, dan juga berdasarkan istikblaf (penugasan 
manusia sebagai khalifah) dan persaudaraan semasyarakat, sebangsa, dan sekemanusiaan.

Apa yang berada dalam genggaman tangan seseorang atau sekelompok orang, pada hakikatnya adalah milik Allah. Manusia diwajibkan menyerahkan kadar tertentu dari kekayaannya untuk kepentingan saudara-saudara mereka. Bukankah hasilhasil produksi, apapun bentuknya, pada hakikatnya merupakan pemanfaatan materi-materi yang telah diciptakan dan dimiliki Tuhan? Bukankah manusia dalam berproduksi hanya mengadakan perubahan, penyesuaian, atau perakitan satu bahan dengan bahan lain yang sebelumnya telah diciptakan Allah? Seorang petani berhasil dalam pertaniannya karena adanya irigasi, alat-alat (walaupun sederhana), makanan, pakaian, stabilitas keamanan, yang kesemuanya tidak mungkin dapat diwujudkan kecuali oleh kebersamaan pribadi-pribadi tersebut, dengan kata lain "masyarakat".

Bukan di sini tempatnya menguraikan macam-macam zakat dan rinciannya, namun yang perlu digarisbawahi bahwa dalam pandangan hukum Islam, zakat harta yang diberikan kepada fakir miskin hendaknya dapat memenuhi kebutuhannya selama setahun, bahkan seumur hidup. Hal itu seperti yang dijelaskan dalam hadis yang artinya: "Rasulullah saw. mewajibkan zakat fitrah sebagai pembersih bagi orang yang berpuasa ... dan makanan bagi orang-orang miskin."'1

Menutupi kebutuhan tersebut dapat berupa modal kerja sesuai dengan keahlian dan keterampilan masing-masing, yang ditopang oleh peningkatan kualitasnya. Hal lain yang perlu juga dicatat adalah bahwa pakar-pakar hukum Islam menetapkan kebutuhan pokok dimaksud mencakup kebutuhan sandang, pangan, papan, seks, pendidikan, dan kesehatan.

${ }^{21}$ Ibn Majah, Sunan Ibn Majah, (Riyad: Maktabah al-Ma'arif, t.t.), h. 318. Hadis senada, dengan redaksi sedikit berbeda, juga diriwayatkan Imam Muslim. Lihat: al-Imam Abu al-Husaini Muslim bin al-Hajjaj bin Muslim al-Qusyairi anNaisaburi, al-Jami' as-Shahih, (t.t.p., t.p., t.t.), hlm. 67. 
3) Filantropi

Filantropi yang diwujudkan oleh masyarakat Islam awal sampai sekarang dalam berbagai bentuk, seperti wakaf, sedekah, zakat, infak, hibah dan hadiah. Dalam perkembangan sejarah Islam, kegiatan filantropi ini dikembangkan dengan berdirinya lembaga-lembaga yang mengelola sumber daya yang berasal dari kegiatan filantropi yang didasari anjuran bahkan perintah yang terdapat dalam al-Quran dan Hadis. Selanjutnya lembaga filantropi ini semakin menunjukkan signifikansinya, di antaranya karena perannya dalam upaya mengurangi kesenjangan sosial (ekonomi) dalam masyarakat, begitu juga dalam bidang pendidikan, yang memiliki misi dakwah dan penyebaran ilmu. Lebih jauh munculnya berbagai lembaga pendidikan Islam, baik yang disebut madrasah, maupun zawiyah tidak dapat dipisahkan dari peran filantropi Islam.

Indonesia memiliki lembaga filantropi yang mengelola zakat, infak, sedekah yaitu Badan Amil Zakat Nasional (BAZNAS) yang merupakan badan resmi dan satu-satunya yang dibentuk oleh pemerintah berdasarkan Keputusan Presiden RI No. 8 Tahun 2001 yang memiliki tugas dan fungsi menghimpun dan menyalurkan zakat, infaq, dan sedekah (ZIS) pada tingkat nasional. Lahirnya Undang-Undang Nomor 23 Tahun 2011 tentang Pengelolaan Zakat semakin mengukuhkan peran BAZNAS sebagai lembaga filantropi yang berwenang melakukan pengelolaan zakat, infak, sedekah secara nasional. Dalam UU tersebut, BAZNAS dinyatakan sebagai lembaga pemerintah nonstruktural yang bersifat mandiri dan bertanggung jawab kepada Presiden melalui Menteri Agama.

\section{c. Kewajiban pemerintah}

Pemerintah juga berkewajiban mencukupi setiap kebutuhan warga negara, melalui sumber-sumber dana yang sah. Yang terpenting di antaranya adalah pajak, baik dalam bentuk pajak perorangan, tanah, atau perdagangan, maupun pajak 
tambahan lainnya yang ditetapkan pemerintah bila sumbersumber tersebut di atas belum mencukupi.

\section{Hikmah di Balik Kemiskinan Hidup}

Allah telah membagikan harta kekayaan milik-Nya di antara pada hamba-hamba Nya dengan ketentuan yang adil dan sesuai dengan keadaan dan kemuliaan mereka. Allah swt. berfirman yang artinya; "Katakanlab: Sesunggubnya Tubanku melapangkan rezeki bagi siapa yang dikehendaki-Nya dan menyempitkan (bagi siapa yang dikehendaki-Nya). Akan tetapi kebanyakan manusia tidak mengetabui." (Q. S. Saba (34): 36) Orang yang belum terbangun keimanan dalam hatinya akan mengira bahwa rezeki yang didapatkan adalah bukti kemuliaan dirinya dari Allah swt. yang diberikan kepadanya. Begitu juga sebaliknya, bahwa rezeki yang dijauhkan darinya adalah bukti kehinaan dirinya dari Allah swt. sebagaimana dijelaskan dalam firman Allah swt. yang artinya; "Adapun manusia apabila Tuhannya mengujinya lalu Dia dimuliakan-Nya dan diberi-Nya kesenangan, maka dia akan berkata: Tubanku telah memuliakanku. Adapun bila Tubannya mengujinya lalu membatasi rezekinya maka dia berkata: Tubanku mengbinakanku.” (Q. S. Saba (89): 15-16)

Seandainya Allah swt. membuat semua hamba-Ny kaya raya, niscaya mereka akan melampui batas. Begitu pula seandainya Dia membuat semua hamba-Nya miskin, niscaya mereka akan binasa. ${ }^{22}$ Maha Suci Allah yang melapangkan dan menyempitkan rezeki atas semua makhluk berdasar hikmahnya yang begitu luas. ${ }^{23}$ Jadi, keadaan hidup yang terbaik adalah keadaan yang telah dipilihkan Allah swt. untuk hamba-Nya. Sesungguhnya kemuliaan kemiskinan tersebut juga disinggung oleh Rasulullah dalam beberapa riwayatnya, diantaranya adalah riwayat yang artinya; "Orang-orang fakir masuk syurga lima ratus tabun lebih setengah hari sebelum orang kaya.” (HR. At-Tirmidzi) ${ }^{24}$

${ }^{22}$ Abu Su'ud, Tafsir Abi Su'ud, Juz 8, hlm. 32.

${ }^{23}$ Mahmud Ahmad Sa'id, Hikmah di Balik..., hlm. 1.

${ }^{24}$ Imal al-Hafizh Muhammad bin 'Isa bin Saurah al-Tirmidzi, Sunan atTirmidri, (Riyadh: Maktabah al-Ma'arif li an-Nasyr wa at-Tauzi', 1417 H), hlm. 
Ar-Raghib al-Ashfahab mengatakan dalam bukunya, wujud kimiskinan dan perasaan takut darinya yang mana keduanya sama-sama melahirkan kemauan keras, adalah dua hal yang mendorong orang untuk bekerja kerasa dan berupaya menaggung beban hidup untuk memberikan manfaat bagi orang lain; baik itu dalam kemauan sendiri maupun karena terpaksa. Seandainya setiap orang tercukupi kebutuhan hidupnya, maka hal tersebut akan mengakibatkan kehancuran hidupnya, maka hal tersebut akan mengakibatkan kehancuran dunia, karena saat itu tidak ada orang yang melakukan sebuah pekerjaan untuk orang lain dan setiap orang tidak bisa melakukan kemaslahatan-kemaslahatan untuk dirinya sendiri, akhirnya semua itu malah membuat miskin mereka semua. Bahkan ditegaskan "majunya dunia lebih banyak disebabkan keadaan yang miskin daripada yang kaya." Sekiranya tidak ada kemiskinan dan perasaan takut darinya, maka kehidupan manusia pun tidak akan beraturan, nanti siapa yang akan menjahit, menyamak, dan menyapu? Adakah orang yang mengangkut makanan dan pakaian dari timur ke barat, dari selatan dan utara? $?^{25}$

Namun demikian, tidak berarti bahwa kemiskinan itu lebih baik daripada kekayaan, karena dalam kemiskinan itu pun banyak sekali cobaannya. Oleh sebab itu, Rasulullah saw. selalu memohon perlindungan kepada Allah swt. dari kejahatan yang muncul akibat kemiskinan ataupun kekayaan. Nabi bersabda; "Ya Allah, aku berlindung kepada-MU dari kejahatan dan siksa api neraka serta dari kejahatan yang timbul akibat kekayaan dan kemiskinan." Jadi, keadaan hidup yang terbaik adalah keadaan yang telah dipilihkan Allah swt. untuk hamba-Nya. Diantara hikmah kemiskinan yang ditentukan oleh Allah swt. atas sebagian hamba-Nya adalah terwujud dinamika hidup, dan lahirnya kemauan keras sebagai

531.

${ }^{25}$ Ar-Raghib al-Ashfahan, Adz-Zari'ab ila Makarimi asy-Syariah, (Kairo: Dar ash-Sahwah, 1985), hlm. 377. 
motivasi untuk berusaha dan bekerja serta memberi manfaat bagi orang lain.

\section{Simpulan}

Kemiskinan adalah problema klasik yang akan selalu ada, dan memiliki pengaruh sangat besar terhadap kehidupan individu maupun sosial. Karena itu, banyak agama dan madzab pemikiran yang berusaha memecahkan persoalan ini. Namun belum ada yang berhasil yang sepenuhnya, karena semuanya berujung pada eksploitasi manusia atas manusia.

Demikian hal kemisikinan adalah musuh besar umat Islam, mereka berkwajiban melawan kemiskinan yang menderanya. Allah swt., tidak pernah memerintahkan penganutnya menjadi orang miskin, kalau kita baca seluruh ayat dalam Alqur'an, maka tidak akan pernah menjumpai ayat yang memerintahkan umat islam menjadi miskin. Allah itu Maha Penyayang, Dia akan membantu umatnya keluar dari segala kesulitan. Begitu juga yang terdapat dalam Hadis dalam berbagai aspek kehidupan Rasulullah merupakan (uswatun hasanah) bagi umat Islam. Khusus berkaitan dengan harta, Rasulullah berulang kali mengajarkan umat Islam agar tidak orang papa dan hina. Pada salah satu sabdanya Rasulullah menegaskan bahwa "tangan diatas lebih baik daripada tangan dibawah" atau berarti memberi lebih baik daripada menerima. Melalui hadis ini, umat Islam diajarkan untuk mau meringankan beban orang lain yang membutuhkan dan sebaliknya. 


\section{DAFTAR PUSTAKA}

Al-Athrasy, Mahmud Ahmad Sa'id, Hikmah di Balik Kemiskinan, Jakarta: Qisthi Press, 2013.

Ar-Razi , Muhammad ibn Abu Bakar, mubktar ash-Shaḅhạh, Damaskus: Mu'assasah Ilmu al al-Qura'an dan Dar al Qiblah al Islamiyah, $1405 \mathrm{H} / 1985 \mathrm{M}$.

Ashfahan, Ar-Raghib, Adz-Zari'ab ila Makarim asy-Syari'ah, Kairo: Dar ash-Sahwah, 1985.

Bukhari, Abu Abdullah Muhammad ibn Ismail, Al-Jami' AshShahih, Kairo: Maktabah salafiah, $1400 \mathrm{H}$.

Gazali, Ibya' Ulum ad-Din, Juz 4, Cet. Ke-1, Kairo: Dar asySya'b,t.t.

Ibn Hanbal, Imam Ahmad ibn Muhammad, Al-Musnad, Juz 8, Kairo: Dar Al-Hadits.

Ibn Katsir, Imam Jalil al-Hafizh 'Imad ad-Din Abi Fida', Tafsir Al-Quran al-Karim, Libanon: Maktabah Aulad li as-Syaikh li at-Turats, t.t.

Ibnu Faris, Mu'jam Maqayis al- Lughah, Juz 4, Cet. Ke-1, Beirut, Dar al-Jail, 1420 H/1999 M

Kahalah,'Umar Ridho, Mu'jam al-Mu'allifin, Juz 3, Cet. Ke-1, Beirut: Muassasah ar-Risalah, t.t.

Khalil, Jafril, Jihad Ekonomi Islam, Jakarta: Gramata Publishing, 2010.

Shihab, M. Quraish, Wawasan al-Quran,Cet. Ke-13, Bandung: Mizan, 2009.

Sijistani, Abu Daud Sulaiman ibn Asy'ats, Sunan Abi Daud, Riyadh: Maktabah Ma'arif, t.t. 
Syakiri, Abdul Haq, at-Tanmiyyah al Iqtishadiyyah fi al-Islam, Qatar: Kitab al-Ummah, No. 17, 1408 H.

Thabarah, Alif, Rub ad-Din as-Islami, Cet. Ke-27, Beirut: Dar-al ilmi li al-Malayin, 1988.

Tim Penyusun, Kamus Besar Bahasa Indonesia, Jakarta: Pusat Bahasa Departemen Pendidikan Nasional, 2008.

Tirmidzi, Imal al-Hafizh Muhammad bin 'Isa bin Saurah, Sunan at-Tirmidzi, Riyad: Maktabah al-Ma'arif li an-Nasyr wa atTauzi', 1417 H . 
Bayu Tri Cahya 